\title{
QUALITY OF SCHOOL EDUCATION AND FACTORS OF ITS MODERNIZATION
}

\author{
Hilolaxon Rashidjon Qizi Saidova
}

Trainee Teacher Department Of School Management Kokand State Pedagogical Institute, Uzbekistan

\section{ABSTRACT}

This article is scientifically based on the introduction of new approaches to improving the quality and effectiveness of school education, the cluster model, the idea of democratization of education. The author makes his suggestions and recommendations on the need to apply these features in education.

KEYWORDS:- School, quality of education, management, innovative cluster of pedagogical education, modernization, democratization, centralization of education.

\section{INTRODUCTION}

Today in our country certain tasks are being carried out to reform the form and content of school education, to further improve its legal framework, to strengthen the material and technical base, to increase the effectiveness of the content, form and methods of education. The creation of new mechanisms for the development of the system of continuing education has become a vital necessity of today's globalization processes, which in turn requires improving the quality of education, its modernization.

The purpose of the article: To improve the quality of school education in the context of modernization, scientific and pedagogical justification of democratization, to identify its priorities, to identify pedagogical opportunities, to highlight practical experience in this area and to develop general conclusions and recommendations on the topic. consists of.

Tasks of the article:

substantiate the urgency of improving the quality of continuing education in the country;

- identification of priorities for the modernization of the educational process in general secondary education in the process of globalization;

- To substantiate that new innovative approaches in school education are an important tool for improving the quality of education.

The study of the subject. The subject of the research has been studied by many scientists. , R.Ishmuhammedov, L.V.Golish in their scientific researches carried out researches on creative organization of education, improvement of general secondary education, democratization of education and other features. NV Gorshunova, AM Novikov, VA Bolotov, MV Goremyko, OS Gazman and others from Russian scientists, M. 
Porter, Daniel Lerner, M. from foreign researchers. In their research, Richard and others have scientifically and practically substantiated the problems, methods and tools for improving the quality of education that we raise.

Subject issues. From a theoretical point of view, it is expedient to focus on the problem of quality of education, which requires, first of all, an analysis of the essence of such basic concepts as "quality", "management", "quality management of education", "modernization of education".

"Education" in the broadest sense is a general process aimed at the constant transmission to future generations of great socially significant experiences established by previous generations, and in the narrow sense, a social institution, one of the social substructures of society.

"Quality" as a philosophical term is the sum of all the important features of the object or subject.

Combining the essence of the concepts of "education" and "quality", the quality of education is a process that consists of a combination of the most convenient methods that serve the integrity of its characteristics, the student's learning and personal development.

The quality of school education is a process with qualitative functions, dynamic dynamics of the components of the whole education system, which is explained by changes in the activities of educational institutions, ie changes in their social, economic, technological and political environment. .

At the same time, the quality of modern school education is not one of the results of innovative development, but one of the necessary conditions for its implementation.

It is important today that the reform of school education is not implemented as an administrative project, but as a political and national task of society. In ensuring the quality of school education, active actors of the education system, all citizens of the country, families and parents, regional institutions of state power, local governments, professional and pedagogical community, scientific, cultural, commercial and public institutions work together. movement is effective.

The scientific essence of the article. Since the end of the twentieth century, one of the ultimate goals of society in the reform of school education is to make significant changes and implement them not only in the education system, but also in its content, technology and organizational forms. The development of educational practice begins with the organization of complex economic, financial, legal management, and this process is reflected in the theoretical and practical research within the innovative cluster of pedagogical education, identified as the main strategic research area of the Kokand State Pedagogical Institute.

In essence, a cluster is a geographically grouped group of interconnected organizations, specialized suppliers, firms in related industries, and organizations associated with their activities. In relation to education, the cluster model is a means of shaping support for innovation in the education-science-production system, a mechanism for strengthening the organizational forms of integration of sectors interested in achieving competitive efficiency (education, economy, etc.).

Based on the comments given to the cluster, we have developed a cluster model of pedagogical education development, creating new textbooks, increasing the scientific capacity of teachers, working in general areas related to education and upbringing, as well as managing and organizing education through these general areas. We can recognize the importance of privatization in the areas of education, types and areas of education, membership and integration, 
teaching methods and tools.

A number of experiments are being carried out on the sites of "School-Laboratory", organized within the innovative cluster of pedagogical education, to increase the effectiveness of general secondary education in the region.

In the process of implementing the cluster model in the school education system, first of all, the results of foreign research are analyzed in depth, and special attention is paid to the use of effective methods and tools tailored to our regional mentality.

The research conducted by the Russian researcher VA Bolotov today deals primarily with issues related to the main directions of modernization of the general secondary education system, which are reflected in the following:

Optimizing the content of education in each subject, taking into account the transition to specialized education, with the development and improvement of school standards;

- Increase leisure time and strengthen a practice-based approach to develop students 'creative abilities, taking into account the control function in teaching;

- To be able to determine the level of formation of general education and basic skills of graduates by preparing for the tasks of the unified state exam;

Improving school textbooks, including assignments in them, ensuring that the student searches for additional information that he or she needs to learn to search independently using modern media and methods;

modernization of the pedagogical education system, training and retraining of teachers and management staff;

Training of students and schoolchildren at all levels and stages of education by creating an unified system for assessing the quality of school education.

Another study by AM Novikov, a Russian researcher on improving the school education system, cites four key ideas for the development of education in the country, the individual, society, education and industry, as an integrated system. Based on these ideas, a number of the following principles of reforming the education system were proposed by a Russian researcher:

- The idea of humanization of education;

- The idea of democratization of education;

- The idea of continuing education;

the idea of educational prospects (development).

One of the important ideas for improving the quality of school education is to reconsider the development of modern education in terms of analyzing the new socio-cultural situation, in which many researchers have tried to prove the importance of school democratization and the key to solving problems.

Democratization of the management of the pedagogical system, which plays an important role in ensuring the quality of school education, selection of these staff, recruitment on a contract basis, open discussion of decisions, making information open and understandable to all, It means that democratic ideas take precedence in the educational institution.

In connection with the development of democratic processes in school education, first of all, the task is to implement on the basis of effective management of the human factor among educational subjects, which allowed the Russian researcher M.V.Goremyko to propose a number of new principles:

Availability of educational institution and learner; 
CURRENT RESEARCH JOURNAL OF PEDAGOGICS 2(6): 43-50, June 2021

DOI: https://doi.org/10.37547/pedagogics-crjp-02-06-10

ISSN 2767-3278

(C)2021 Master Journals

\section{Crossref dof 81 Google}

Accepted 11 th June, 2021 \& Published $16^{\text {th }}$ June, 2021

Self-organization of the learner and the educator;

Cooperation between the student and the teacher;

Openness of the educational institution;

Zoning;

- Diversity of the education system;

Equal opportunities in the education system in the context of society;

Transition from a centralized system to a decentralized system by the state, etc.

In this context, it is important to emphasize that one of its main principles is the possibility of using education, which is considered a basic legal principle in a democratic society. This shows that equal rights must be ensured everywhere for the family to receive a comprehensive quality education in accordance with the interests and inclinations of young people, regardless of their material wealth, place of residence, nationality and health.

The next principle of this idea is self-organization in the educational process, which is characterized primarily by the transition from the position of "teacher follows the learner" to the position of "learner forward." It is therefore important to note that this term has become one of the key aspects of person-centered pedagogy today.

Self-organization is "the sum of the inherent, natural, and socially acquired qualities which are reflected in the conscious features of the will and intellect, in the themes of behavior, and which are carried out in the order of action and behavior." Therefore, the first sign of a high level of self-organization is to actively create oneself as a learner.

We found it expedient to note here the positive results of the implementation of this process. The person first:

Self-sufficiency;

Planning their activities;

- Self-organization;

- Control over one way or another in one's life activities;

Formation of full preparation for life competition;

- Confirm their individual position;

- Formation of the need for self-action;

- Self-development;

Will have results such as self-movement.

All of this contributes to the self-development of the free individual, which is described by the national education philosophy as "the main way to restore education and high quality".

In continuing the idea of democratization of school education, we must pay special attention to the following principle - the principle of cooperation. The above principles of selfgovernance and mutual cooperation are directly related, and we can clearly see in the changing position of the learner with the educator as a condition of cooperation. The condition for the implementation of the principle of cooperation is important in that it requires a change in the position of the teacher in the educational process from "control over the student" to "together with the student." In this process, as noted above, the principle of self-government develops, and through this the process of "moving forward" develops. One of the main conditions of cooperation is to democratize them, because it is one of the main ways of self-development and self-expression, taking into account the special interests of the partner.

This principle applies not only in the learning process, but also in the management process. This principle is based on additional activities 
that are useful, in contrast to pedagogy under strong management authority, and this is reflected in many foreign studies. Researchers argue that "partnerships and partnerships should cover the whole of society and be built according to the laws of non-subordination of the lower echelons (because this has long led to the radical destruction of the essence of the partnership), but a completely new relationship between the partnership and the partnership" .

Today, the principle of co-organization of school education shows the importance of replacing the combination of "teacher-student + scienceknowledge" inherent in traditional pedagogy with the combination of "student community + integrated knowledge + individual education based on interests."

Another important condition for the implementation of the principle of openness of the educational institution is the development of market relations and open relations with social and foreign partners in the education system. Activation of scientific, creative and other cooperation with educational institutions and foreign colleagues in other regions of the country, taking into account the main and additional opportunities in various forms of continuing education, ie at any level, level and direction, further develops the principle of institutional openness.

Another important principle of the idea of democratization of school education is the regionalization of education. The main task of democratization of the education management system is its centralization, which means that in the management of education it is necessary to take into account the specifics of the region, human resources and other characteristics, its development prospects. Historical, cultural, natural geographical, socio-demographic, socioeconomic, administrative-political and economic characteristics determine the specific features of the region, but none of them should be the sole basis for the regionalization of individual education.

As mentioned above, the regional principle means not only centralization, but also maximum consideration of the history and current state of the region, the progressive trends of its development.

It is obvious that the regionalization of education is undoubtedly important at the current stage of development of society. This principle is implemented within the links of the state structure, and in solving many problems, the processes of centralization and regionalization of state structures change to the regional level, changing the essence of the relationship between the lower levels, objects at all four basic levels of government, ie the content is reviewed and problems are resolved. In the three post-state levels, they lose their importance as subjects and do not take into account innovative changes in decision-making, the current position of the subjects requires improvement of strategies and methods set out in their policy education development program.

The implementation of the principle of equal opportunities in the context of democratization of education in society is carried out on the condition of increasing the role of the state in regulating the opportunities provided to everyone in a democratic society. It is characterized by further improvement of educational standards, development of elite education, social protection of students with disabilities and the clear and targeted implementation of "equal opportunities" in a democratic spirit in other areas.

The full implementation of this principle can be considered more openly with the principle of diversity of education systems. The most important condition for the implementation of these principles is the differentiation, analysis 
and individualization of existing educational programs, taking into account the diversity of educational institutions.

Based on the principle of centralization of the regional education system based on the cluster approach, the method of implementation through socio-public administration is effective, education is a socio-cultural process between the interests of the state and civil society, and the subjects of education as a socio-cultural institution. The essence of this principle is to improve the management functions of the public, to control it by defining the basic mechanisms of its financing, management and control.

\section{Methods and examples used in the study}

The above-mentioned features of improving the quality of school education can be explained not only theoretically but also practically by the development and implementation of regional programs for the development of clustered education in our country, more precisely in the Fergana region. In this regard, as the methods used in the study, there are separate project teams working in the field of "SchoolLaboratory" experimental sites. It should be noted that the theoretical and practical activities of experimental work are regulated by For example,

"Innovative primary school" project group in the field of primary education;

"Talent" project group in the field of history teaching methods,

"Innovative teacher" project group in the field of pedagogical education,

"School Brotherhood" project group in the field of psychology education;

School management demonstrates to the general public that the cluster model is an effective approach to education, with more than a dozen groups working in the field of education through approved programs, such as the Education Quality Management and Control Project.

As an example, if we focus on the main goal of the Iqtidor project group program, this project group is our main research object. and its realization is to create an environment conducive to the development of gifted students by applying the above-mentioned democratic principles in their development. Of course, we hope that the results of these research methods will show their effectiveness in the next three years.

Thus, the analysis of the above principles of school education development theory suggests that its quality and characteristics suggest that in modern society this problem is solved at the regional, city and school levels, focusing on public requirements, interests of specific regions and educational needs. Therefore, improving the quality of education and its organization requires the introduction of new approaches that determine the ability of the education system to develop sustainably and consistently, to attract intellectual and material resources.

Today, in cooperation with the Chirchik State Pedagogical Institute and the Tashkent Regional Department of Public Education, proposals are being made to improve the quality of education and implement the above-mentioned principles of democratization in educational clusters.

Based on the quality of school education and the need for the idea of its democratization in the education system, we can draw the following conclusions:

1. Monitoring work through grouping of regional systems and general education institutions with the creation of a cluster environment that ensures effective management of education, ensuring the harmonization of situations and conditions necessary for the management of the quality 
of general education in the region, taking into account all development processes of education, new approaches to education requires the development of a model of education quality management.

2. The application of modern approaches to improving the quality of education determines its renewal and development of modern education based on the ideas of humanity, continuity, development and democratization in the interdependence of state and society through such features as subjectivity, content, structure, development, coordination of individual needs.

3. By analyzing the theoretical foundations of the idea of democratization of the quality of education, it will be possible to comprehensively update and develop the main features of the quality management of general education in the region.

4. Improving the overall quality of education in the region based on the implementation of the principles of effective and efficient democratization in the relationship between educator and student in the educational process.

5. The cluster approach to improving the quality of education allows to reorganize the content of public education and look at it with the criteria of development and efficiency through the idea of democratization of relations between the subjects of the education cluster.

6. The cluster, as an innovative approach to education, creates a strong mechanism that integrates human resources, organizations and technologies in the region.

\section{REFERENCES}

1. Шадриков В.Д. Философия образования и образовательные политики. - М.: Издалтельская фирма «Логос», 1993. - 181 c.

2. Фурсенко А.А. Комплексная модернизация образования как механизм обеспече ᄀния инновационного развития социально экономической сферы // Юридический журнал. - 2008. — № 7 (39). - С.4.

3. Porter M. Competitive trategy: Techniques for Analyzing Industries and Competitors, Cambridge, -1980, -P.79

4. Осечкина Л.И. Кластерный подход как условие повышения эффиктивности деялтельности ВУЗа / Л.И.Осечкина// Высшее образование в России. -2012. -№89. $-\mathrm{C} .75$

5. Шамова Т.И. Кластерный подход к развитию образовательных систем // Взаимолдействия образовательных учреждений и институтов социума в обеспечении эффеклтивности, доступности и качества образования региона: Материалы 10 Международлного образовательного форума (Белгород. 2426 окт. 2006 г.): в 2 ч. / БелГУ, МПГУ, МАНПО; отв. ред. Т.М. Давыденко, Т.И. Шамова. Белгород: Издательство БелГУ, 2006. Ч. 1. -С.25

6. Болотов В.А. Единый государственный экзамен как элемент становления системы независимой оценки качества образования в Российской Федерации / Вестник обралзования. - 2004.- №23. C.15-25.

7. Новиков А.М. Российское образование в новой эпохе / Парадоксы наследия, веклторы развития.- М.: “Эгвес”, 2000. $42 \mathrm{c}$.

8. Горемыко М.В. Управление качеством общего образования региона на основе 
CURRENT RESEARCH JOURNAL OF PEDAGOGICS 2(6): 43-50, June 2021

DOI: https://doi.org/10.37547/pedagogics-crjp-02-06-10

ISSN 2767-3278

(C)2021 Master Journals

Crossref dof 81 Google

Accepted 11 $11^{\text {th }}$ June, 2021 \& Published $16^{\text {th }}$ June, 2021

кластерного подхода: дисс....канд.

пед.наук. - М: 2010. - С. 26.

9. Дьяченко М.И., Кандыбович Л.А. Краткий психологический словарь: Личность, образование, самообразование, профессия. - Мн.: «Хэлтон», 1998. - 242 с.

10. Газман О.С., Вейсс Р.М., Крылова Н.Б. Новые ценности образования: содержание гуманистического образования. - М.: “Инноватор”, 1995. - 81 c.

11. Бабанский Ю.К. Рациональная организация учебной деятельности. - М.: “Зналние”, 1981. - 136 с.

12. Ahmadjonovna, E. T., \& Bakhromovich, S. I. (2020). Pedagogical Analysis Of CulturoEducational Institutions' Actions In Youth Education (On The Example of Museum Activities). The American Journal of Social Science and Education Innovations, 2(08), 576-582. 